\title{
The schema-based mathematics study: Enriching mathematics teaching and learning using a culture-sensitive curriculum
}

\author{
Anthony N. Ezeife (University of Windsor)
}

\begin{abstract}
Declining enrolment in mathematics and related fields is a common problem in present-day academic world. In many indigenous cultures worldwide, the flight from mathematics and science, noticeable even in advanced, technologically oriented societies, assumes alarming proportions. In Canada, for example, low enrolment and high dropout rates from mathematics and science courses are common among aboriginal students. The few who persist and complete their mathematics courses in high school often end up with low grades, a situation that has resulted in the paucity of qualified aboriginal students in mathematics-related careers at higher levels of education. Several researchers have opined that the situation arises due to the lack of relevance of school mathematics and science to the aboriginal learner's everyday life and culture. Therefore, they argued that cultural practices, ideas, and beliefs (the students' schema) that would connect the school to the community in which it exists and functions should be incorporated into the mathematics curriculum. This study implemented an innovative (culture-sensitive) mathematics curriculum, developed with the active participation of community Elders, in the Walpole Island First Nation elementary school in Ontario, Canada. Results showed that students who were taught with the culture-sensitive curriculum performed significantly better than their counterparts taught with the existing (regular) provincial curriculum.
\end{abstract}

\begin{abstract}
Résumé
Les inscriptions décroissantes en mathématiques et domaines annexes représentent un problème majeur de niveau international dans le monde académique. Cette fuite des mathématiques et des sciences qui a lieu non seulement dans les cultures autochtones mais aussi dans les sociétés technologiquement avancées prend des proportions alarmantes. Au Canada par exemple, les étudiants autochtones s'inscrivent peu en mathématiques et en sciences ou abandonnent souvent ces études. Ceux qui persistent et qui finissent leurs cours de mathématiques au lycée obtiennent souvent des notes assez basses, une situation qui entraine une pénurie d'étudiants autochtones qualifiés en mathématiques et domaines annexes à l'université. Certains chercheurs pensent que cette situation est due au fait que les mathématiques et sciences scolaires n'ont aucun rapport avec la vie quotidienne et la culture des étudiants autochtones. C'est la raison pour laquelle ils pensent que les pratiques culturelles, les idées et les croyances des communautés locales (schémas des étudiants) devraient être insérées dans les programmes de mathématiques. Ceci permettrait de connecter l'école directement aux communautés. Cette étude a mis en œuvre un curriculum de mathématiques innovant et sensible à la culture. Il a été conçu avec la participation active des anciens de la communauté dans l'école élémentaire des Premières Nations de l'Île de Walpole en Ontario au Canada. Les résultats montrent que ceux qui ont suivis les cours par le biais du curriculum basé sur la culture ont eu des résultats nettement supérieurs à ceux qui ont suivi les programmes provinciaux officiels.
\end{abstract}

\section{INTRODUCTION}

The issue of lack of interest, and consequent low enrolment in school mathematics and science courses has been recognized in the educational setting for a long time (Alonge, 1982; Bates, 1977; Davison, 1992; Ezeife, 1989; Matthews, 1989). This issue is, unfortunately, still inadequately addressed 
especially as it affects students in the developing world, and learners of ethnic minority and Indigenous cultural backgrounds in Western societies (Assembly of Manitoba Chiefs, 1999; Ezeife, 2006; Mel, 2001; Smith \& Ezeife, 2000). Related to the issue of low enrolment in mathematics and science by Indigenous and ethnic minority students is the problem of poor performance in examinations by the relatively few students from these cultural backgrounds who venture into these areas of study (Binda, 2001; Friesen \& Ezeife, 2009; Johnson, 1999; Katz \& McCluskey, 2003). The low enrolment and poor performance, in turn, culminate in the under-representation of this category of students in mathematics, science, and related disciplines. Citing Lawrenz and McCreath (1988), Schilk, Arewa, Thomson, and White (1995) lucidly described the situation, stating: "Native Americans have the lowest representation percentage of all minorities in scientific careers and are at risk in pursuing science in high school and postsecondary education" (p. 1). Davison (1992) particularly highlighted the status quo in mathematics, saying: "What cannot be questioned is that the mathematics achievement of American Indian students as a group is below that of white students in the United States" (p. 241). The plight of Canadian Aboriginal students closely resembles that of Native American students with regard to low enrolment, substandard achievement, high dropout rates, and hence, underrepresentation in science, mathematics, and technological fields, as observed by several researchers (Binda, 2001; Ezeife, 2006; Ignas, 2004; MacIvor, 1995). For instance, commenting on the situation in the province of British Columbia, Canada, Ignas (2004), stated: "Research continues to document the persistent nature of under-representation of Indigenous students in science and professional programs leading to certification" (p. 51).

Historically, research findings attest to the fact that long before contact with Western civilizations, Aboriginal people were not just active practitioners in the realm of mathematics, science, and astronomy, but also actually excelled in these fields - recording time-tested accomplishments in these challenging areas of endeavour. For example, Smith (1994) has drawn attention to the feat attained in ancient times by the Skidi Pawnee, an Aboriginal group, who by studiously and enthusiastically observing outer space and the constellations, were able to identify the planet Venus. Also, by patiently and correctly tracking the movements of the stars and planets, the same group "conceptualized the summer solstice", and "...in this way they could predict the reoccurring summer solstice" (Smith, 1994, p. 46). Similarly, writing from the privileged stance of a native Pueblo, the anthropologist, Oritz (1969) documented the informative, age-old interactions of space, time, and being of the Pueblo people, an Indigenous North American civilization. Additionally, many authors and researchers (D'Ambrosio, 
1985; Cajete, 1994; Ezeife, 2006; Hatfield, Edwards, Bitter, \& Marrow, 2004) have recorded several remarkable mathematical and scientific achievements and practices of various Indigenous cultures across the globe, dating back to several centuries of history. With the foregoing as the background, one then wonders why contemporary Indigenous students, for example, Canadian Aboriginals, shy away from mathematics and science - the very disciplines in which their progenitors excelled.

\section{THEORETICAL FRAMEWORK: WHY THE FLIGHT FROM MATHEMATICS?}

Many contemporary educational researchers (Ezeife, 2002; Hauffman, 2001; Ignas, 2004; Matang, 2001; Smith \& Ezeife, 2000; Pewewardy, 2002; Piquemal \& Nickles, 2005; Snively \& Corsiglia, 2001) agree that there is a discontinuity between the home or community culture of Indigenous students and the education they receive in mainstream schools in North America and other parts of the world. For instance, in drawing attention to this discontinuity, Piquemal and Nickels (2005) cited Hauffman's (2001) cultural discontinuity hypothesis which "suggests that differing cultural elements between in-school and out-ofschool experiences...have a significant effect on young Aboriginal students' school experiences" (p. 119). Aboriginal students are often faced with hazardous cultural border crossing situations (Jegede \& Aikenhead, 1999) as they make the transition from their life-world culture into the mainstream school culture, especially in the fields of mathematics and science. Essentially, this situation arises because the mathematics and science taught in school is bereft of Aboriginal cultural, traditional, and environmental content (Smith, 1994; Ezeife, 2006). Thus, from the perspective of Aboriginal students, the curricula used to teach them, especially in the disciplines of mathematics and science, are not meaningful and relevant since, as Ignas (2004) emphasized: “...meaningful curriculum must necessarily be rooted in local knowledge and history and this is especially so in the case of Indigenous students whose typical experience of mainstream education is one that has distanced and denied First Nations knowledge" (p. 49). Realizing that their life-world culture is not reflected in the curriculum, a spontaneous feeling of foreignness and alienation sprouts, and with passing years, takes a firm root in the students, with regard to the school subjects in question. This feeling of foreignness toward mathematics and science by Aboriginal students leads to a distaste for these fields of study, poor performance in them, with the consequent and foreseeable, if familiar result - underrepresentation of this group of students in scientific and technological fields. 
This paper builds on the theoretical framework that a mathematics curriculum fashioned to include Aboriginal learners' life-world culture that is centred on the environment in which they live, their flora and fauna, their schema, traditional knowledge and values, and their communal experiences and aspirations - would strike a firm chord of harmony with the learners. Additionally, it is further theorized that such a curriculum, if implemented with full cognizance of, and adherence, to the holistic teaching approach that has reportedly facilitated learning for students from high-context Indigenous cultural backgrounds (Ezeife, 2003), would enable Canadian Aboriginal students not only to change their negative attitude to school mathematics but would, in addition, enable them record improved performance in this subject area. The schema-based mathematics study reported in this paper involved the development and implementation of a theory-backed culture-sensitive mathematics curriculum in an Aboriginal community school. The term 'schema', as used in this context, refers to the global or generalized views of past experiences, or an individual's mental maps, that have saliency or prominence for the individual (Anderson, 1972).

\section{METHOD}

The study dwelt on the development and implementation of the curriculum in Grades 5 and 6 classes of the community school in Walpole Island, a First Nations community in Ontario, Canada. The project was executed in three interrelated phases:

\section{Phase 1: Tapping and compiling Indigenous mathematics knowledge.}

In this phase of the study, the archival holdings of the Walpole Island Heritage Centre (Nin Da Waab Jig) - a research centre that has functioned in the Island since 1973 (Jacobs, 1992) - were extensively examined, and valuable resource materials on the past and current mathematics-related traditional practices in the Anishnabe-speaking First Nations community were obtained. This was followed up with several field visits to sites of mathematical interest in the Island such as the High Banks park, traditional log houses, communal recreational facilities, the picturesque confluence of the bodies of water that border the Island, the Tall Grass zone, and some communal farms. Furthermore, several community Elders, including the then Chief of the community, and other knowledgeable Indigenous educators were interviewed in a loosely guided, and largely free-flowing interview format. During the interviews they were prompted with leading questions to narrate, and explicate traditional practices, phenomena, folklore, and stories in their culture and environment that have relevance to mathematics. As 
detailed in Appendix A, ten broad themes of interest or topics were the focus of the interview, though the Elders/educators were encouraged to bring up and discuss any topic not covered or listed in the ten broad areas of focus that might be of interest to them. Tapping into the wealth of Indigenous Knowledge possessed by community Elders was a key goal of this study because I share the position of Ignas (2004) that a relevant curriculum should be largely hinged on local knowledge and history.

\section{Phase 2: Interview analysis and integration}

After transcribing the audio-taped interview records, the transcripts were sent back to the interviewees for cross-checking, confirmation, and possible modifications. When they received the transcripts, some of the interviewees surprisingly added new material to their original submissions. This was indicative of their enthusiastic involvement in the study. It also brought into the open the fact that they had done their own research in the intervening period between the interview and the returning of the transcripts, to find out more information on the interplay of their culture, traditional life, environment, and mathematics - from an Anishnabe community perspective.

A group comprised mostly of Indigenous graduate students in the researcher's team was then charged with gleaning and itemizing the mathematics content from the interview transcripts, and categorizing the content into relevant strands of the Ontario mathematics curriculum, Grades 1 to 8 . In correspondence with the curriculum, the content fell into one or more of the following strands Number Sense and Numeration, Patterning and Algebra, Geometry and Spatial Sense, Data Management and Probability, and Measurement. The researcher then edited the categorized mathematics content prepared by the graduate students and finally integrated these materials from the interviews, and those earlier gleaned from the archival holdings of the Heritage Research Centre, into the existing Ontario mathematics curriculum. This gave rise to an innovative (culturesensitive) curriculum, styled the integrated curriculum. Sample categorizations from the interviews and archival holdings, adapted from Ezeife (2006) are shown in Appendix B.

\section{Phase 3: Classroom implementation of the integrated curriculum}

The instructional phase of the study was carried out in Grades 5 and 6 over a oneyear period for the same set of students. Thus, at the beginning of the study, when the students were in Grade 5, a convenience sample of 28 participants was struck from the existing Grade 5 classes in Walpole Island community school. The sample was then divided into two groups with 14 students in each group. 
Randomization procedures were then used to assign each of the two groups to a treatment condition. Students in the "regular curriculum" instruction group constituted the control group (Group A), and were taught with the regular (existing) Grade 5 Ontario mathematics curriculum which does not contain culture-prone materials. On the other hand, the students in the experimental group (Group B) were instructed with the integrated (culture-sensitive) curriculum.

A highly dedicated teacher of Aboriginal origin, who was recruited from a pool of certified teachers, served as instructor for both groups, thus controlling for teacher variability factor. Before the commencement of instruction, the two research groups were given the same pretest to ascertain their Entry Behaviour and readiness for the study. Additionally, the researcher mounted an intensive two-week training workshop for the instructor at which appropriate classroom mannerisms, the approaches to adopt to ensure the coverage of the same course (subject-matter) content for each group, the need for a deep commitment to the study, and the importance of the study to the overall development and enhancement of mathematics education were extensively discussed. However, to control for instructor bias, the instructor was not informed about the intended comparison of the existing (regular) and integrated curriculums.

Furthermore, to minimize, if not completely eliminate, a possible Hawthorne effect (Gay \& Airasian, 2003), and to control for test anxiety, the participants were re-assured, as per their informed consent to participate, that their academic performance in the study would not affect their school grades in any manner. In other words, that their scores in the quizzes and tests given in the study would not be transferred to their school records. However, both instructional groups were informed of the ultimate goal of the study - the overall improvement of their mathematics education, and the need for them to participate actively in all the learning experiences during class sessions. Again, to make the study fit closely with the regular school routine, and to maintain students' focus throughout the study, Continuous Assessment exercises and end-of-unit quizzes were factored into the instructional format. Also, the teaching times and testing conditions were made uniform for the two groups. The researcher effectively monitored instructor compliance and course material coverage all through the four weeks of instruction, thereby ensuring that the intended curriculum materials were adequately implemented. The instruction in Grade 5 covered two strands Number Sense and Numeration, and Geometry and Spatial Sense of the Ontario Grades 1-8 curriculum (2005).

In line with the thrust and focus of the study, most of the lessons on Geometry and Spatial Sense were taught in a traditional log house kindly 
provided by a community Elder. Doing the lessons in a real life geometrical setting enabled the students to see firsthand the relationships among the various angles, planes, and elevations that were webbed together to constitute the completed log house. They were able to measure and record the dimensions of various constituent units of the house both in the interior and exterior parts of the structure. The students' enthusiasm even extended to guided forays into the attic of the house where they made measurements of whatever component units attracted them, and of their own volition, matched these units with some geometrical shapes they had studied, for instance, polygons, cylindrical shapes, pyramids, and so on. Finally, they drew and labeled a sketch of the log house, noting on it any distinct geometrical observation that particularly stood out for them.

When the students moved on to Grade 6, the two groups, which remained intact, were again instructed by another teacher of Aboriginal origin, who also underwent a similar workshop training mounted by the researcher before the commencement of instruction. To ensure an adequate measure of continuity and retention, the Grade 6 instruction commenced early in the school year, covering the remaining three Ontario math strands - Algebra and Patterning, Measurement, and Data Management and Probability. The Grade 6 instruction lasted six continuous weeks. As was the case in Grade 5, most of the lessons in the three strands were done in outdoor natural settings. For instance, many of the Data Management and Probability lessons were taught in the High Banks park in the Island where the students carried out learn-as-you-do experiments using the circumferences of the trees (which they measured) to set up ratio relationships. From the measurements, they were able to accurately predict the ages of some of the trees, aided by data on the trees supplied by the park keepers. Also, they successfully collected and analyzed data on the diameters of the trees in the park, the distances (spacing) between nearby trees, and the optimal abundance of trees in a typical park. Armed with such data, the students were able to complete the unit project that required them to create on paper a "dream park" of their own, that they could translate into a real community park as they grow up. At the end of the six weeks of instruction both groups were given the same posttest.

\section{RESULTS AND FINDINGS}

As earlier stated, to test the Entry Behaviour of the control and experimental groups, the two groups were given the same pretest at the beginning of the study in Grade 5. The results of the pretest are shown in Table 1, while Table 2 gives the ANOVA summary for the pretest scores. 


\begin{tabular}{|c|c|c|c|}
\hline Groups & No. of participants & Curriculum type & Mean score \\
\hline A (Control) & 14 & Regular curriculum & 33.85 \\
\hline B (Experimental) & 14 & Integrated curriculum & 35.85 \\
\hline Total & 28 & & 34.85 \\
\hline
\end{tabular}

Table 1: Pretest mean scores of participants in instructional groups $(\mathrm{N}=28)$

\begin{tabular}{|l|l|l|l|l|}
\hline Source of Variance & Sum of Squares & df & Mean Square & F \\
\hline Between groups & 28.00 & 1 & 28.00 & 0.284 \\
\hline Within groups & 2559.43 & 26 & 98.44 & \\
\hline Total & 2587.43 & 27 & & \\
\hline
\end{tabular}

Table 2: ANOVA summary for pretest scores

$$
\mathrm{p}>0.05 \text { (Fcrit. }=4.23)
$$

At the end of the study in Grade 6, the two groups were given the same posttest a mathematics achievement test (MAT) based on the subject-matter content covered during the instructional phases of the study in Grades 5 and 6.

Tables 3-5 give the results of the posttest.

\begin{tabular}{|c|c|c|c|}
\hline Groups & No. of participants & Curriculum type & Mean \\
\hline A (Control) & 14 & Regular curriculum & 39.86 \\
\hline B (Experimental) & 14 & Integrated curriculum & 54.79 \\
\hline Total & 28 & & 47.33 \\
\hline
\end{tabular}

Table 3: Posttest mean scores of subjects in instructional groups $(\mathrm{N}=28)$

\begin{tabular}{|c|c|c|c|c|c|}
\hline Source of Variance & Sum of Squares & df & Mean Square & F & Sig. \\
\hline Between groups & 1560.036 & 1 & 1560.036 & $8.315^{*}$ & 0.008 \\
\hline Within groups & 4878.071 & 26 & 187.618 & & \\
\hline Total & 6438.107 & 27 & & & \\
\hline
\end{tabular}

Table 4: ANOVA summary for posttest scores

$$
* \mathrm{p}<0.05(\text { Fcrit }=4.23)
$$

\begin{tabular}{|c|c|c|c|c|c|c|c|c|}
\hline \multirow{2}{*}{$\begin{array}{l}\text { Curriculum } \\
\text { type }\end{array}$} & \multirow[b]{2}{*}{$\mathrm{N}$} & \multirow[b]{2}{*}{ Mean } & \multirow[b]{2}{*}{ Std. Dev. } & \multirow[b]{2}{*}{ Std. Error } & \multicolumn{2}{|c|}{$\begin{array}{l}95 \% \text { Confidence Interval for } \\
\text { Mean }\end{array}$} & \multirow[b]{2}{*}{ Min. } & \multirow[b]{2}{*}{ Max. } \\
\hline & & & & & Lower Bound & Upper Bound & & \\
\hline Regular & 14 & 39.8571 & 11.88960 & 3.17763 & 32.9923 & 46.7220 & 26.00 & 67.00 \\
\hline Integrated & 14 & 54.7857 & 15.29293 & 4.08721 & 45.9558 & 63.6156 & 32.00 & 83.00 \\
\hline Total & 28 & 47.3214 & 15.44177 & 2.91822 & 41.3337 & 53.3091 & 26.00 & 83.00 \\
\hline
\end{tabular}

Table 5: Further descriptive statistics

\section{SUMMARY AND DISCUSSION OF RESULTS}

The pretest mean score of Group A (the control group) was 33.85, while Group B (the experimental group) recorded a mean of 35.85. The Analysis of Variance 
summary in Table 2 indicated there was no statistically significant difference between these mean scores. This finding implies, therefore, that there was no significant difference between the performances of the two groups at the time of commencement of the study in Grade 5. Thus, no group was at an initial advantageous position over the other in terms of its mathematics attainment or readiness. The two groups were, therefore, deemed equivalent at the beginning of the study.

\section{Hypothesis}

The study was guided by the null hypothesis that there would be no significant difference between the posttest mean scores of the control group and the experimental group. However, the Analysis of Variance revealed there was actually a significant difference in favour of the experimental group - the group taught using the integrated (culture-sensitive) curriculum. Thus, the students taught by this method out performed their counterparts in the control group taught with the regular (existing) curriculum. Hence, the null hypothesis was rejected at the 0.05 significance level. I would also like to note that the Analysis of Variance test was also significant even at the 0.01 level $\left(\mathrm{F}_{\text {crit. }}=7.72\right)$. So, the null hypothesis of no difference would also be rejected at that level. Thus, the type of curriculum used in teaching mathematics to the students played a significant role in the performance of the students over and above what would be expected by chance.

Additionally, the further descriptive statistics given in Table 5 indicate that the best overall performing participant who had a score of 83 came from the experimental group while the maximum score in the control group was 67 . Similarly, the minimum score of 32 recorded in the experimental group was also higher than the minimum score of 26 in the control group. Hence, from all indications, the students taught with the culture-sensitive curriculum performed better than those taught with the regular curriculum

\section{LIMITATIONS}

The unavoidable use of convenience sampling procedures in selecting the research participants for this study may be considered a limitation. However, to minimize the possible effect of this limitation, randomization was used to assign the two Grade 5 classes to instructional groups. Also, as a further check and experimental control aimed at ensuring the equivalence of the groups, the same pretest was administered on the two groups and this revealed that no group was at an initial advantage over the other at the beginning of the study. 
The relatively small sample size was also a limiting factor that could not be controlled because that was the entire Grade 5 population in the community school. However, the fact that there was no case of attrition or experimental mortality in the transition from Grade 5 to 6 , provided considerable stability in the study. The long duration of the study (four weeks in Grade 5 and six weeks in Grade 6), and the building of instructor permanence into the design of the study ensured a high measure of continuity not just in content presentation, course coverage, and teaching style, but also in teacher-student rapport and the establishment of favourable learning environments in both groups.

\section{RECOMMENDATIONS AND CONCLUSION}

Based on the findings of this study, I would strongly recommend that Huffman's (2001) "cultural discontinuity hypothesis", as cited in Piquemal and Nickels (2005, p. 119) be addressed in all schools that have Aboriginal students. This hypothesis postulates that "differing cultural elements between in-school and outof-school experiences...have a significant effect on young Aboriginal students' school experiences". The approach I adopted in this study was aimed at tackling the cultural discontinuity hypothesis. Thus, Aboriginal (specifically, Anishnabe) cultural content was incorporated into the integrated mathematics curriculum in terms of knowledge base - Aboriginal mathematics knowledge culled from the environment and the archival holdings of the Walpole Island Heritage Centre, and traditional mathematics knowledge readily put at the disposal of the researcher by community Elders and educators. In addition, this study injected classroom experiences similar to the early cultural socialization experiences of Aboriginal learners. For instance, emphasis was placed on learn-as-you-do mathematics teaching and learning techniques, and in-class demonstrations and exercises. This approach mirrors the age-old apprenticeship system of knowledge and skill acquisition popular among Indigenous cultures worldwide, including Canadian Aboriginal people. Also, still in line with the early cultural socialization experiences of Aboriginal learners, end-of-unit quizzes were administered as consolidating exercises aimed at diagnosing learners' strengths and weaknesses, instead of competitive, ranking-oriented school examinations. Furthermore, outdoor mathematics teaching/learning approaches were freely utilized, for example, the log house Geometry sessions, and the Data Management and Probability lessons in the High Banks park.

I would also recommend that significant efforts be made by all teachers and educational institutions to enable Aboriginal learners experience smooth cultural border crossing (Ezeife, 2003) as they navigate the transition from their life-world culture (acquired from home, peers, and community) to the culture of 
school mathematics. A smooth cultural border crossing learning experience would enhance "simultaneous collateral learning", a situation "in which learning a concept in one domain of knowledge or culture can facilitate the learning of a similar or related concept in another milieu" (Aikenhead \& Jegede, 1999, p. 24). In other words, a smooth cultural border crossing experience can help Aboriginal students "apply what they already know to novel learning opportunities" as suggested by Ignas (2004, p. 52), a suggestion I unreservedly reinforce.

Referring to Indigenous epistemology, Greenwood and de Leeuw (2007, p. 48) affirm that "teachings flow from stories". Thus, these authors encourage the use of stories in teaching - a technique often referred to as the storyline approach (Ezeife, 2002). The present study utilized the storyline approach effectively in teaching relevant mathematics concepts to students in the culturesensitive curriculum group. For instance, sharing of the bannock cake - a local delicacy - was used to introduce the relationships among the circumference, diameter, radius, and arc of a circle. The story was told of a group of six children who were given a large bannock cake to share, and were supplied with strings, measuring tapes, cutting boards, and kitchen knives. The challenge posed to the class was to come up with strategies for sharing the cake such that each of the six children would get an equal piece. Having been given this life-related story, the class was then divided into working groups to strategize, and later articulate their ideas in a general discussion session. From the discussion, linkages were built from the story of the bannock cake to the geometry concepts referred to above, hence transferring ideas from a familiar staple food item in the community to a related mathematics learning experience, using a reliable Indigenous learning method - the storyline approach. Based on this positive learning outcome, I would recommend the use of the storyline approach in teaching mathematics to Canadian Aboriginal students.

In conclusion, I would briefly touch on the economic dimension of mathematics education, and draw attention to the urgent need for the labour market in every country to adapt to industrial and commercial innovations on the global scene. Since most of these innovations are technologically focused, this is an added reason for the youth to embrace subjects like mathematics and science that would give them a strong foothold in an environment of technological innovations. Considering the fact that Aboriginal people constitute a sizeable percentage of the Canadian population, it follows that the Canadian economy will benefit from whatever contributions Aboriginal youth can make to the continued growth of the economy. It is, therefore, essential that such youth be fully equipped to make this contribution by preparing them early in life to pursue enabling mathematics-related courses. A timely and early introduction of a 


\section{culture-sensitive mathematics curriculum, which this study has found to be of}

appeal to Aboriginal students, and produced better results than the regular (existing) curriculum, would hopefully dispel the current math phobia prevalent among Aboriginal mathematics learners. This, in turn, would lead to improved mathematics performance, and hopefully an inclination to pursue mathematicsrelated careers and engagements in later years, thereby ending the current underrepresentation of Aboriginal people in scientific, mathematical, and associated technological fields.

\section{References}

Aikenhead, G.S. \& Jegede, O.J. (1999). Cross-cultural science education: A cognitive explanation of a cultural phenomenon: [On-line]. Available: http://www.usask.ca/education/people/aikenhead/970759.htm

Alonge, E.I. (1982). The relevance of traditional methods in modern education: A quest for relevant science education in Africa. Journal of the Science Teachers Association of Nigeria, 21(1), 34-44.

Anderson, O.R. (1972). Teaching modern ideas of biology. New York: Teachers College Press.

Assembly of Manitoba Chiefs (1999). Manitoba First Nations Schools Needs Assessment Report. Winnipeg: Author.

Binda, KP. (2001). Aboriginal education in comparative and global perspectives: What has research and practice done for aboriginal education in Canada? Canadian and International Education, 30(1), $1-16$.

Cajete, G.A (1994). Look to the mountain: An ecology of indigenous education. Skyland, N.C.: Kivaki Press.

D'Ambrosio, U. (1985). Ethnomathematics and its place in the history and pedagogy of mathematics. [On-line]. Available: http://www.enc.org/topics/equity/articles.

Davison, D.M. (1992). Mathematics. In J. Reyhner (Ed.), Teaching American Indian Students, (pp. 241-250). Norman: University of Oklahoma Press.

Ezeife, A.N. (1989). The impact of the three-phase instruction technique on students' performance in physics. Journal of the national foundation for educational research in England and Wales, 31(3), $227-$ 231.

Ezeife, A.N. (1999). Using the schema theory in science teaching: The challenge before the aboriginal science teacher. WESTCAST conference proceedings, 43-56. Brandon: Faculty of Education, Brandon University, Manitoba.

Ezeife, A.N. (2002). Mathematics and culture nexus: The interactions of culture and mathematics in an aboriginal classroom. International Education Journal, 3(3), 176-187.

Ezeife, A.N. (2003). The pervading influence of cultural border crossing and collateral learning on the learner of science and mathematics. Canadian Journal of Native Education, 27(2), 179-194.

Ezeife, A.N. (2006). Culture-sensitive curriculum: The Walpole Island experience. In J.P. White, S. Wingert, D. Beavon, \& P. Maxim (Eds.), Aboriginal policy research: Moving forward, making a difference, Vol. III (pp. 53-66). Toronto: Thompson Educational Publishing, Inc.

Friesen, J. \& Ezeife, A.N. (2009). Making science assessments culturally valid for Aboriginal students. Canadian Journal of Native Education, 32(2), 24-37.

Gay, L.R. \& Airasian, P. (2003). Educational research: Competencies for analysis and applications. Upper Saddle, New Jersey: Merrill Prentice Hall.

Greenwood, M. \& de Leeuw, S. (2007). Teachings from the land: Indigenous people, our health, our land, our children. Canadian Journal of Native Education, 30 (1), 48-53.

Hatfield, M.M., Edwards, N.T., Bitter, G.C, \& Morrow, J. (2004). Mathematics methods for elementary and middle school teachers. New York: John Wiley \& Sons Inc.

Huffman, T. (2001). Resistance theory and the transculturation hypothesis as explanations of college attrition and persistence among culturally traditional American Indians. Journal of American Indian Education, 40(3), 1-23.

Ignas, V. (2004). Opening doors to the future: Applying local knowledge in curriculum development. Canadian Journal of Native Education, 28(1\&2), 49-60. 
Jacobs, D.M. (1992, Aug.). Sustaining the circle of life. Proceedings of the thirteenth North American Prairie Conference, 1-5. Windsor, Ontario, Canada.

Jegede, O.J. \& Aikenhead, G. (1999). Transcending cultural borders: Implications for science teaching. Journal for Science and Technology Education, 17, 45-66.

Johnson, K.A. (1999). Comparing math scores of black students in D.C.'s public and catholic schools. A report of the Heritage Center for Data Analysis. Washington: Heritage Foundation.

Katz, H. \& McCluskey, K. (2003). Seeking strength-based approaches in aboriginal education: The "Three Stars and a Wish" project. McGill Journal of Education, 38(1), 116-134.

MacIvor, M. (1995). Redefining science education for aboriginal students. In M. Battiste and J. Barman (Eds.), First Nations Education in Canada: The circle unfolds, (pp. 73-98). Vancouver: University of British Columbia press.

Matang, R.A. (2001, July). The role of ethnomathematics in mathematics education: Implications for mathematics curriculum in Papua New Guinea. Paper presented at the $11^{\text {th }}$ World Congress of Comparative Education Societies (WCCES), Korea National University of Education, Chungbuk, South Korea.

Matthews, M.R. (1989). A role for history and philosophy in science teaching. Interchange, 2(2), 3-15.

Mel, M. (2001, July). Teacher as caregiver: The introduction of values education through indigenous education in teacher education at the University of Goroka. Paper presented at the $11^{\text {th }}$ World Congress of Comparative Education Societies, Korea National University of Education, Chungbuk, South Korea.

Oritz, A. (1969). The Tema world: Space, time, being and becoming in a Pueblo society. Chicago, IL: University of Chicago Press.

Pewewardy, C. (2002). Learning styles of American Indian/Alaska Native students: A review of the literature and implications for practice. Journal of American Indian Education, 41(3), 23-56.

Piquemal, N. \& Nickels, B. (2005). Cultural congruence in the education of, and research with young Aboriginal students: Ethical implications for classroom researchers. The Alberta Journal of Educational Research, 51(2), 118-134.

Schilk, J.M., Arewa, E.O., Thomson, B.S., \& White, A.L. (1995). How do Native Americans view science? COGNOSOS, The National Center for Science Teaching and Learning Research Quarterly, 4(3), 1-4.

Smith, M.R. \& Ezeife, A.N. (2000, May). Using the environment in science teaching: A cross-cultural perspective. Paper presented at the Canadian Society for the Study of Education (CSSE) conference, University of Alberta, Edmonton.

Smith, M.R. (1994). Scientific knowledge and cultural knowledge in the classroom. In K.P. Binda (Ed.), Critical issues in First Nations Education (pp. 38-54). Brandon: BUNTEP, Faculty of Education, Brandon University, Brandon, Manitoba.

Snively, G. \& Corsiglia, J. (2001). Re-discovering indigenous science: Implications for science education. Science Education, 85(1), 6-34.

The Ontario Curriculum, Grades 1 -8: Mathematics (2005). Toronto: Ministry of Education and Training.

\section{ACKNOWLEDGEMENTS}

This study was carried out with a grant from the Social Sciences and Humanities Research Council of Canada (SSHRC) - Aboriginal. The contribution (in kind) of the Aboriginal Education Centre (Turtle Island) of the University of Windsor is also hereby acknowledged.

Anthony N. Ezeife is a Professor of Mathematics and Science Education in the Faculty of Education, University of Windsor. His main research focus is on the improvement of science, technology, and mathematics (STM) education in traditional and indigenous settings world-wide. He can be reached at aezeife@uwindsor.ca. 


\section{Appendix A}

\section{Interview instrument for community elders and educators.}

\section{Introduction}

It is known that Aboriginal people had a deep knowledge of mathematics and science in the past, and regularly used and applied this knowledge in their daily lives and activities. For example, the Skidi Pawnee were reputed astronomers and were able to predict and interpret the movement of heavenly bodies and stars.

\section{Purpose of Interview}

Our discussion in this interview is meant to seek information on how the lives of community members of Walpole Island involve mathematics in today's world, and had involved math in the olden days. Please, tell us what you know about mathematics in the cultural and traditional life of the community. For instance, you could talk about mathematics as it affects the following aspects of life and activities:

\section{Traditional housing}

Anishnabe names of types of local/traditional houses could be given. You could talk about the shapes of the houses, how they were partitioned, materials and equipment used in their construction, their elevation (how high or low they were), their positioning - facing/backing the sunrise, capacity (the approximate number of people the houses could hold, their length, width, and height - approximately).

\section{Traditional occupational activities and transportation}

This could be discussed under these headings:

Fishing - Local instruments and equipment used for fishing in the past, ice fishing - approximate depth and width of fishing holes, temperature ranges during periods of ice fishing, fishing teams, and so on.

Farming - Sharing of farmlands, approximate sizes of farming plots, how the plots were measured, including the instruments used, how farm products were stored, and so on.

Hunting - Hunting traps and gear, shape of traps - any angles involved in the preparation/setting of traps, and reasons for shaping the traps in a particular fashion, hunting teams and expeditions, etc. Any other occupational activities? Tell us about any other such activity you know.

Transportation - Local/traditional means of transportation used in the olden days, their names and how they were built, seasons of the year when they were used.

Folklore - traditional stories, beliefs, customs, etc. usually handed down by word of mouth from generation to generation by Elders. Any numbers, counting, weights, heights, areas and volumes involved in these stories?

Games - Names of popular Anishnabe games played in the olden days by both young and old people, times of the year they were played, instruments and equipment used to play them, number of people taking part, purpose of the games?

Clothing and Decoration - Names, types, styles, and uses of traditional clothes and feathers, ceremonial occasions when used, who is entitled to wear what types of clothes and why? Seasons of the year they were worn? Decorations used in the traditional culture, purpose of these decorations. Any special patterns of art in traditional clothes and decorations?

Eating and Drinking - Names, types of food, and sizes of food rations, sizes of traditional drinking cups, their shapes, etc.

Counting and Record Keeping - "Base" system used (that is, after how many numbers does the person counting begin again from a specific base/starting point of the counting cycle). Note to the interviewer: Here, explain that the current base system in the Western world is the decimal (base ten) system, while the computer uses the base two or binary system.

Time and Time Keeping, Calendar - How was time observed and recorded in the culture of the people in the past? Keeping of appointments, instruments and equipment used to keep time, how were they made? How many days were there in the traditional week (or whatever local name by which the 'week' was called)? Month? Year? How were these records kept?

Measurement - How were distances, speed, weights, etc, measured? What standards or units were used to record these measurements?

General - Please, tell us any Anishnabe story that involves mathematics - numbers, counting, running, bending, angles, weighing of objects, duration of activities, sunrise and sunset, sleeping habits of people and animals, and so on. Whatever you can think of is acceptable to us.

Appreciation: Thank you very much for discussing and sharing your ideas on, and knowledge of, mathematics with us.

Name of person interviewed

Interviewed by

Date of Interview 


\section{Appendix B}

Sample categorizations of analyzed interviews into mathematics strands, teaching topics, and concepts.

\begin{tabular}{|c|c|c|}
\hline $\begin{array}{l}\text { Relevant math content gleaned } \\
\text { from interview }\end{array}$ & Corresponding math Strand & Applicable math topic/concept \\
\hline $\begin{array}{l}\text { Farmers picking strawberries } \\
\text { with large bowls. }\end{array}$ & Measurement & $\begin{array}{l}\text { Capacity and Volume }- \text { different } \\
\text { amounts in containers of different } \\
\text { shapes and sizes, for example, the } \\
\text { volumes/capacities of household } \\
\text { utensils, cans, cups, bottles, and other } \\
\text { everyday containers. }\end{array}$ \\
\hline $\begin{array}{l}\text { Use of "willow" to make a } \\
\text { "dream catcher" frame. }\end{array}$ & Geometry and Spatial Sense & $\begin{array}{l}\text { Construction; angles involved in the } \\
\text { frame; types and measures of angles. }\end{array}$ \\
\hline $\begin{array}{l}\text { Beadwork and beads worn by } \\
\text { the Anishnabe. }\end{array}$ & Patterning and Algebra & $\begin{array}{l}\text { Patterns in the beadwork, colours and } \\
\text { ordering of beads. }\end{array}$ \\
\hline $\begin{array}{l}\text { Making moccasins } \\
\text { "sometimes requires } \\
\text { measuring the feet of someone } \\
\text { standing on the hide". }\end{array}$ & Measurement & $\begin{array}{l}\text { Units and standards of units, Conversion } \\
\text { between different systems of units - The } \\
\text { SI system, fps, etc. }\end{array}$ \\
\hline $\begin{array}{l}\text { "Many", in the Anishnabe } \\
\text { language "means a whole } \\
\text { bunch of something". For } \\
\text { example, "in case of berries, it } \\
\text { could be a pail full of berries". }\end{array}$ & Number sense and Numeration & $\begin{array}{l}\text { Counting, basic units of counting, } \\
\text { different base systems. }\end{array}$ \\
\hline $\begin{array}{l}\text { Flowers in the environment. } \\
\text { "Sometimes, we picked } \\
\text { flowers and counted the } \\
\text { petals". }\end{array}$ & $\begin{array}{l}\text { Number sense and Numeration; } \\
\text { Patterning and Algebra. }\end{array}$ & $\begin{array}{l}\text { Numeric skills, Naturalistic intelligence } \\
\text { (Gardner's Multiple Intelligences); } \\
\text { Patterns in the arrangement of the petals. }\end{array}$ \\
\hline $\begin{array}{l}\text { Hunting: "The rounded tipped } \\
\text { arrows are used for hunting } \\
\text { smaller game, while the } \\
\text { sharpened tips are used for } \\
\text { hunting larger game". }\end{array}$ & Geometry and Spatial Sense. & $\begin{array}{l}\text { Angles, Shapes, and Velocity of Motion. } \\
\text { (Link the "V" or tip of the arrowhead, } \\
\text { which leaves a wake that follows the } \\
\text { rest of the arrow to flight of birds in "V" } \\
\text { formation - the other birds follow the } \\
\text { lead "squad" with less effort). }\end{array}$ \\
\hline $\begin{array}{l}\text { Housing: "The shape of the } \\
\text { lodges is usually circular". } \\
\text { "...the construction of the } \\
\text { lodges is symbolic. At the } \\
\text { centre of the lodge is a hold for } \\
\text { the fire, and at the top of the } \\
\text { roof is a circle for smoke exit. } \\
\text { The doorways of the lodges } \\
\text { agree with the four directions - } \\
\text { East, West, North, and South". }\end{array}$ & Geometry and Spatial Sense & $\begin{array}{l}\text { Coordinate Geometry - Directions and } \\
\text { locations in space. The four cardinal } \\
\text { points and the formation of the four } \\
\text { quadrants. }\end{array}$ \\
\hline $\begin{array}{l}\text { Fishing: The technique the } \\
\text { Anishnabe use is to make } \\
\text { "marsh grass in a circular } \\
\text { formation. A hole inside the } \\
\text { formation is lined with } \\
\text { tunnels; often six or more } \\
\text { tunnels are linked to the hole". }\end{array}$ & $\begin{array}{l}\text { Data management } \\
\text { Probability }\end{array}$ & $\begin{array}{l}\text { Probability - its example and } \\
\text { application in an everyday life situation. } \\
\text { (The Anishnabe technique involves } \\
\text { running the fish through several tunnels } \\
\text { until they are captured in one. This } \\
\text { strategy adopts, and exemplifies the } \\
\text { principle of probability). }\end{array}$ \\
\hline
\end{tabular}




\begin{tabular}{|l|l|l|}
\hline $\begin{array}{l}\text { Burial Traditions: "Burying of } \\
\text { a loved one is usually on the } \\
5^{\text {th }} \text { day...the body is positioned } \\
\text { to the East which symbolizes a } \\
\text { new beginning - where the sun } \\
\text { rises". }\end{array}$ & $\begin{array}{l}\text { Nhe decimal (base 10) system of } \\
\text { counting contrasted with the base 5 } \\
\text { system. The concept and use of "place } \\
\text { holder" in counting. Cycles and } \\
\text { rotations. Directions - sunrise and } \\
\text { sunset. }\end{array}$ \\
\hline $\begin{array}{l}\text { Games: "Gaming was a } \\
\text { traditional activity, almost like } \\
\text { present-day casinos There } \\
\text { were shell games, slide-of - } \\
\text { hand tricks, the moccasin } \\
\text { game, etc. In the moccasin } \\
\text { game, the target is for each } \\
\text { player to correctly guess in } \\
\text { which pouch a specially } \\
\text { marked marble was hidden". }\end{array}$ & $\begin{array}{l}\text { Probability. } \\
\text { involving chance - such as raffles, } \\
\text { lotteries, and bingos. Determination of } \\
\text { the odds of winning. }\end{array}$ \\
\end{tabular}

